\title{
Gastrointestinal Stromal Tumor pT1 TNM Finding v8
}

National Cancer Institute

\section{Source}

National Cancer Institute. Gastrointestinal Stromal Tumor pT1 TNM Finding v8. NCI

Thesaurus. Code C136760.

Gastrointestinal stromal tumor measuring $2 \mathrm{~cm}$ or less. (from AJCC 8th Ed.) 